\title{
Analysis Of Factors That Influence The Quality Of Life Of People Life With Hiv/Aids (Plwha) In Dr. R. Sosodoro Djatikoesoemo Bojonegoro Hospitals
}

\author{
Ahmad Maftukhin, Nurwijayanti, \\ Siti Farida Noor Layla \\ Strada Indonesia Health Sciences \\ Institute \\ Email: \\ ahmad.maftukhin@gmail.com
}

\author{
ABSTRACT
}

Background: People with HIV / AIDS need support from the surrounding community, but in reality the opposite is the community's stigma of people with HIV / AIDS is still negative, this has the effect of being isolated from the surrounding community so that the quality of life of people with HIV / AIDS is not optimal.

Purpose: The purpose of this study is to analyze the factors that affect the quality of life of people with HIV / AIDS.

Methodhs: The design of this study was analytic with cross sectional approach, the population was 427 respondents, the sample size was calculated using the Slovin formula as many as 78 respondents, the type of sampling used was side probabilities with systematic random sampling technique.

Results: The results of this study were tested using an ordinal regression test, and the results showed that the significance value of the effect of adherence to ARV consumption on the quality of life of PLWHA was 0.223, nutritional status significance value 0.498 and social support significance value 0.000. So of the three independent variables studied, the effect was only the social support variable because the significance value was below 0.05 .

Conclusion : factors that affect the quality of life of PLWHA are social support factors.

Keywords: nutritional status, quality of life, social support

Copyright (C) 2020 IIK STRADA Indonesia All right reserved.

This is an open-acces article distributed under the terms of the Creative Commons Attribution-ShareAlike 4.0 International License.

\section{INTRODUCTION}

People living with HIV / AIDS need support because this disease is chronic and requires comprehensive treatment ( $\mathrm{Li}$, et al, 2008). Diseases associated with HIV-infected people will quickly improve with the comfort of family, support of friends and loved ones (Green \& Hestin, 2009). There are still many PLHIV sufferers who lack support from their families and people around them. This is caused by the high negative stigma associated with HIV / AIDS so that family members who suffer from this disease are often considered to have violated family norms and are embarrassing the family. Social support is obtained from family support, peer support, and community support (Carter, 2012). The growing understanding in families and communities of people living with HIV makes families tend to isolate people living with HIV. These psychological problems can affect the ability of PLHIV to participate fully in their treatment and care, thus affecting the quality of life of PLHIV (Hardiansyah, 2011). Quality of life is an important factor that needs to be considered for mental and 
physical health of PLWHA that can contribute to the satisfaction and happiness of the individual itself and provide benefits to the family and community (Mardhiati, 2011). Based on the description above, researchers are interested in conducting research on "the factors that affect the quality of life of PLHIV (people living with HIV / AIDS) in the Sehati Poly Hospital Dr. R. Sosodoro Djatikoesoemo Bojonegoro 2020 "which aims to identify the effect of adherence to ARV consumption, social support and nutritional status on the quality of life of PLHA. And also to identify which of these three factors most influences the quality of life of PLWHA. Purpose of this study is to analyze the faktor of compliance with ARV consumption, nutritional status and support for quality of life of people live with HIV/AIDS

\section{MATERIALS AND METHODS}

The design of this study used an observational study design, the approach used in this study was cross sectional, the total population of 427 people living with HIV after being calculated using the Slovin formula found the results of 78 . So the respondents in this study were 78 respondents with the type of probability sampling with the technique used was systematic random sampling. The measuring instrument used in this study was a questionnaire that had tested its validity and reliability. This measuring instrument has been tested for ethical feasibility both from the Health Research Ethics Commission of Strada Indonesia number: 1686 / KEPK / 1/2020, as well as from the research area of Dr. R. SOSODORO DJATIKOESOEMO BOJONEGORO, with director's decree number: 445 / D33 / 412.202.1 / SK / 2020

\section{RESULTS}

Based on these results after testing using the Ordinal Regression test using a significance level of $\alpha$ 0.05 in accordance with the purpose of the study that is connecting adherence to ARV consumption, social support and nutritional status with quality of life of PLWHA, the results are obtained: variable adherence to ARV significance of 0.223 , variable Nutritional status has a significance value of 0.498 , while social support has a significance value of 0.000 , thus the factor influencing the quality of life of PLWHA is social support, because the significance value is below 0.05 .

Table 1. Case Processing Summary

\begin{tabular}{llrr}
\hline & & & Marginal \\
& & & Percentage \\
\hline \multirow{3}{*}{ Kualitas hidup ODHA } & Less & 18 & $23.1 \%$ \\
& Enough & 53 & $67.9 \%$ \\
& Good & 7 & $9.0 \%$ \\
Status Gizi & Less & 23 & $29.5 \%$ \\
& Normal & 50 & $64.1 \%$ \\
Kepatuhan ARV & High & 5 & $6.4 \%$ \\
& Enough & 42 & $53.8 \%$ \\
Dukungan social & High & 36 & $46.2 \%$ \\
& Less & 22 & $28.2 \%$ \\
Valid & Medium & 44 & $56.4 \%$ \\
Missing & High & 12 & $15.4 \%$ \\
Total & & 78 & $100.0 \%$ \\
\hline
\end{tabular}

Table 2. Parameter Estimates

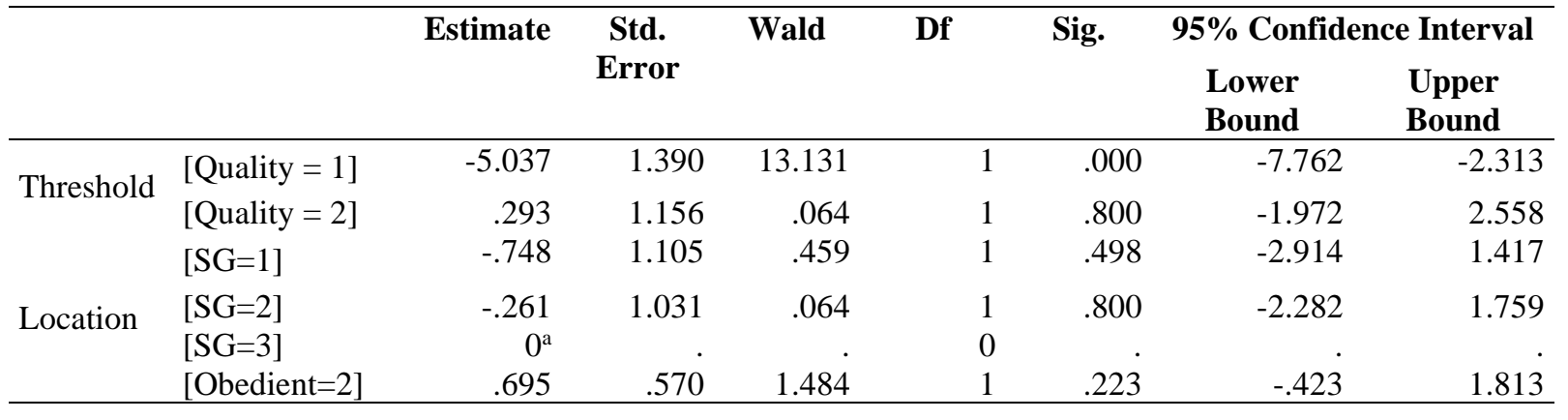




\begin{tabular}{lrrrrrrr}
\hline$[$ Obedient $=3]$ & $0^{\mathrm{a}}$ &. &. & 0 &. &. & -3.147 \\
{$[$ Support=1] } & -5.312 & 1.105 & 23.117 & 1 & .000 & -7.477 & -1.091 \\
{$[$ Support $=2]$} & -2.929 & .938 & 9.753 & 1 & .002 & -4.767 &. \\
{$[$ Support=3] } & $0^{\mathrm{a}}$ &. &. & 0 &. &. &. \\
\hline
\end{tabular}

\section{DISCUSSION}

Based on the results of the statistical tests above, according to researchers based on the theory states that social support affects the quality of life. This is in line with the facts that exist in the field of social support affect the quality of life. HIV / AIDS sufferers who get low social support, the quality of life will also be less, while HIV / AIDS sufferers who get high social support, the quality of life will be quite good. As found in the research location that during treatment the respondent is always accompanied and get motivation from friends of respondents who are members of the community called Dukungan Sebaya (KDS) group. It is also caused by several factors including age, most of the research results (75\%) are still in the productive age category so they can work as usual. Next is the education factor, low education will be more easily directed by people who are considered to understand more, this is in accordance with general research data where the majority of respondents' education (73.07\%) is primary education and not schooling, the next factor is employment, general data research shows that more than half PLHIV sufferers (58.97\%) still have a church, this makes them still feel accepted in the community so that this becomes their own motivation for PLHIV to act as the community in general and have a good enough quality of life, and other factors that affect the quality of life of PLHA are duration of illness, from the results of the study obtained the majority of data (90.99\%) long infected with 1-5 years, in theory the most likely ODHA still does not show symptoms that appear physically, so they can still carry out normal and sustaining activities their quality of life.

\section{CONCLUSION}

The most influential factor on the quality of life of PLWHA in Polati Sehati RSUD Dr. R. Sosodoro Djatikoesoemo Bojonegoro is social support.

\section{ACKNOWLEDGMENTS}

The author would like to thank all participants of this research.

\section{CONFLICTS OF INTEREST}

The author declares that they have no conflict of interest

\section{REFERENCES}

Burhan, Zuhroni. (2014). Gambaran Kebermaknaan Hidup Orang Dengan HIV/AIDS (ODHA) Serta Tinjauannya Menurut Islam. Jurnal Psikogenesis. Vol. 2, No. 2/ Juni 2014. Diakses tanggal 30 November 2019.

Carter, M. (2014). Study identifies issues affecting the quality of life of patients living with HIV. Diakses pada tanggal, 23.

Depkes, RI. (2017). Profil Kesehatan Indonesia Tahun 2016. Jakarta : Kementerian Kesehatan Republik Indonesia

Dinas Kesehatan Kabupaten Bojonegoro. (2017). Profil Dinas Kesehatan Kabupaten Bojonegoro Tahun 2017. Bojonegoro: DinKes Kabupaten Bojonegoro.

Dinas Kesehatan Kabupaten Bojonegoro. (2018). Profil Dinas Kesehatan Kabupaten Bojonegoro Tahun 2018. Bojonegoro: DinKes Kabupaten Bojonegoro.

Setiati S,dkk. (2014). Buku Ajar Ilmu Penyakit Dalam Jilid 3 ed 5. Jakarta : Pusat Penerbit Ilmu Penyakit Dalam.

Donsu. (2016). Metodologi Penenlitian Keperawatan.Yogyakarta: Pustaka Baru Pres.

Hidayat, AAA. (2014). Metode Penelitian Keperawatan Dan Teknik Analisis Data. Jakarta : Salemba Medika.

Kementrian Kesehatan RI. (2015). Rencana Strategis Kementrian Kesehatan Tahun 2015-2019. Jakarta : Kementrian RI. 
Kementrian Kesehatan RI. (2017). Profil Kesehatan Indonesia Tahun 2017. Tersedia di http://www.depkes.go.id/resources/download/pusdatin/ profil-kesehatan-indonesia/profilkesehatan-indonesia-2011.pdf. Diakses Tanggal 23 Oktober 2019.

Kurniawan, Yudianto dkk. (2008). Kualitas Hidup Pasien DM di Rumah Sakit Umum daerah Cianjur .vol10.No.XVIII. Diakses Pada Tanggal 26 Oktober 2019.

Nursalam, Kurniawati. (2018). Asuhan Keperawatan pada Pasien Terinfeksi HIV/ AIDS Edisi 2. Jakarta: Salemba Medika.

Nursalam.(2016). Metodologi Penelitian Ilmu Keperawatan. Jakarta : Salemba Medika.

Octaviani, R. (2013). Kualitas Hidup Seorang Penderita TBC. Skripsi. Surabaya : UIN Sunan Ampel.

RF Rozi, Af Widodo, V. Nami Yulian, N.Msc. (2016). Hubungan Dukungan Social dengan Kualitas Hidup ODHA. Diakses pada tanggal 10 Oktober 2019

Sugiyono. (2016). Metode Penelitian Kuantitatif, Kualitatif dan R\&D. Bandung: Alfabeta

Sujarweni, VW. (2014). SPSS untuk Penelitian. Yogyakarta: Pustaka Baru

Triani Banna, Inggerid A Manoppo. (2019). Kualitas hidup ODHA ditinjau dari kepatuhan minum ARV, Diakses pada tanggal 10 Oktober 2019

Unzila, Syahru Romaddhaan, Nadhirah, Siti Rahayu, Triono Erwin Astawa. (2017) e-journal. Uniar.ac.id, Hubungan kepatuhan ART Satu Bulan Terakhir dengan kualitas hidup pasien HIV/AIDS. Diakses pada tanggal 10 Oktober 2019. 